Historic, Archive Document

Do not assume content reflects current scientific knowledge, policies, or practices. 


\title{
FALL, 1928
}

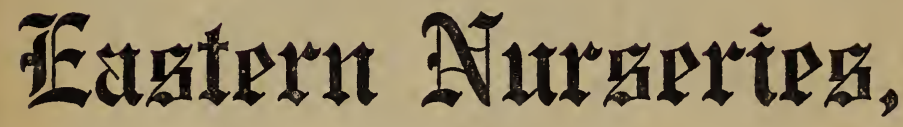

\author{
Jntrarparated
}

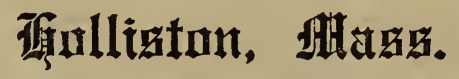

\section{PRICE LIST}

Address all communications to EASTERN NURSERIES, INC., HOLLISTON, MASS.

Telephone, Natick 0345

Telegraph Address, Natick, Mass. 
thiti

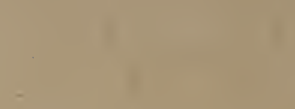

re

s.

x

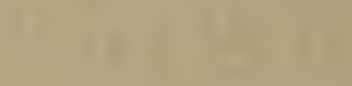

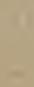

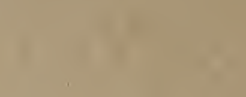

(1)

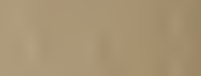

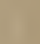

1.

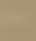

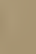

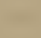

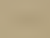

$=$

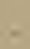

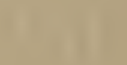

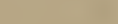

17

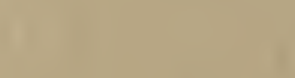

4.

-

$s$

y

I 


\section{F A L L, 1928 Eastern Nurseries, Inc.}

Office and Nurseries, HOLLISTON, MASS.

SHIPPING SEASON opens about March 20 to April 1 in the Spring, and continues until May 20 to June $\mathrm{r}$, and opens about October $I$ in the Fall, and continues until the ground freezes. Shipping for summer planting of Evergreens opens about August 15th. Pot-grown plants can be shipped and planted at all times.

ORDERS.-Write plainly and give explicit directions as to address and mode of shipment; otherwise we will forward according to our best judgment. All goods travel at purchaser's risk. We assume no responsibility for the goods after delivery to the forwarding companies.

When losses occur by delays in delivery, claims should be made at once on the forwarding companies.

CLAIMS, to receive consideration, must be made within ten (10) days of receipt of goods.

While we exercise the greatest care to have all Trees, Shrubs and Plants genuine and reliable, and hold ourselves prepared to replace, on proper proof, all that prove untrue, we do not give any warranty. expressed or implied; and in case of an error on our part, it is mutually agreed between the purchaser and ourselves that we shall not at any time be held responsible for a greater amount than the original price of the goods.

PACKING.-We take great care in packing, using damp moss to protect roots. Boxes and bales are charged for at cost.

RATES.-The prices in this list supersede all previous rates, and apply to quantities specified, but two hundred and fifty (250) will be furnished at the thousand rate, forty (40) at the one hundred rate, and five (5) at the ten rate, except in the case of perennials when 25 of one kind will be given at the Ioo rate. Specimens personally selected by the purchaser or his representative (or specially selected by us at the request of the purchaser) will be priced according to individual values.

This Price List cancels all previous lists and prices are subject to change without notice.

TERMS, CASH WITH ORDERS, except to such persons as satisfy us as to their responsibility. Bills are due when presented and interest will, be charged at the rate of six per cent. on bills remaining unpaid December $\mathrm{I}$ in $\mathrm{F}$ all and June $I$ in Spring.

A Certificate of Inspection will accompany each shipment. Address all communications to office. 


\section{PRICE LIST \\ Eastern Nurseries, Inc.,}

William F. Dawson, President

Henry S. Dawson, Vice-President

L. B. Dawson, Sec.-Treas.

\section{Office and Nurseries at HOLLISTON, MASS.}

Located twenty-six miles southwest of Boston.

\section{FALL, 1928}

Our Evergreens are in especially fine condition this year. Most of them have been transplanted recently and all of them are in excellent condition for Spring planting. We wish to call special attention to our small Evergreens suitable for hedges, group planting and window-boxes, and to our large specimens for immediate effects. Many of these specimens are of unusual beauty and can be moved on platforms, at special prices, which we will gladly quote upon request.

Note.-Look on pages 12 to 19 at our list of Pot-grown Scotch Heather and other ground covers.

A cordial invitation is hereby extended to visit our nursery at any time for the purpose of plant study, or for inspection of saleable stock.

EASTERN NURSERIES, INC.

This Catalogue has been corrected in accordance with the new Book of Standardized Plant Names by the American Joint Committee on Horticultural Nomenclature

\section{EVERGREEN TREES AND SHRUBS}

The prices of Evergreens include the burlapping of balls up to 5 feet.

Note: On all specimen Evergreens over $12 \mathrm{ft}$. price will include canvas and platform when dug.

Abies concolor White FIR

Each $\quad 10 \quad 100$

All beautiful specimens

I5 to $20 \mathrm{ft}$. ... \$75.00 to $\$ 100.00 \$ \$$

homolepis (brachyphylla) NIKo $F_{I R}$

I6 to $20 \mathrm{ft}$. spec.... 75.00

veitchil VEITCH FIR

18 to $24 \mathrm{ft}$. spec. $\$ 75.00$ to 125.00

Andromeda floribunda See Pieris

Plant Bearberry and Scotch Heather near the sea 
Eaon

Azalea ledifolia (indica alba) Snow Azalea

8 to ro in. bushy 4 in. pots $\$ 1.50 \$ 12.50 \$ 115.00$ See also pot-grown plants

Hazel Dawson red New Dawson HyBRID

8 to ro in. bushy 4 in. pots . 4.00

Chamaecyparis

pisifera aurea

Golden Sawara Retinospora

5 to $6 \mathrm{ft}$........ 9.00

filifera THREAD RETINOSPORA

4 to $5 \mathrm{ft}$....... 9.00

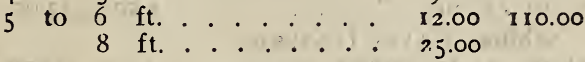

plumosa Plume Retinospora

I $\frac{1}{2}$ to $2 \mathrm{ft}$. . . . . . $3.50 \quad 33.00$

2 to $2 \frac{1}{2} \mathrm{ft} . \ldots . . . .45042 .00$

$2 \frac{1}{2}$ to $3 \mathrm{ft}$........ 500

4 to 5 ft. . . . . . . 7.50

6 to $8 \mathrm{ft} . \ldots . . . .25 .00$

aurea

Golden Plume Retinospora

2 to $2 \frac{1}{2} \mathrm{ft} . \ldots . . .2450$

$2 \frac{1}{2}$ to 3 ft. 5.00

Euonymus radicans WINTERCKEEPER
$3 \mathrm{yr} \cdot \cdot \cdot \cdot \cdot 75 \quad 6.00$
carrieri GLOSSY WINTERCREEPER
$3 \mathrm{yr}$ " . . . 1.00 8.00
vegetus BIGLEAF WINTERCREEPER
2 yr. strong . . . $\quad 75 \quad 6.00$
3 yr. strong... . $1.00 \quad 8.00$

llex glabra INKBERRY

Juniperus chinensis pfitzeriana PFITZER'S JUNIPER

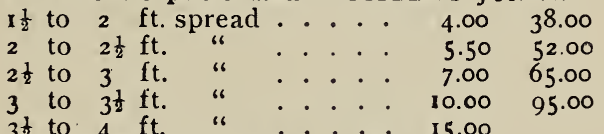

A few large specimens $\$ 50^{\circ}$ to $\$ 60$ each

chinensis sargenti SARGENT TRAILING JUNIPER

8 to 12 in. ...... 3.50

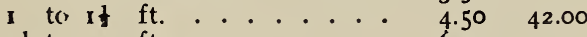

$\mathrm{It}$ to $2 \mathrm{ft}$....... 6.00

$2 \frac{1}{2}$ to $3 \mathrm{ft}$. spread . . . . $\mathbf{2} 2.50$

3 to $3 \frac{1}{2} \mathrm{ft}$. spread .... 16.00

Juniperus communis COMMON JUNIPER

$\mathrm{I} \frac{1}{2}$ to $2 \mathrm{ft}$...... $33.50 \quad 33.00$

Note. The upright Juniper is one of the very hardiest evergreens, and one of the most satisfactory for the New England climate. It keeps its color all winter, and fruits when still quite small. depressa FieLd JUNIPER
18 to 24 in. spread $3.25 \quad 30.00$ aurea GoLden FIELD JUNIPER 15 to 18 in. 3.00 
Juniperus communis hibernica IRISH JUNIPER

Each $10 \quad 100$

$$
\begin{aligned}
& 2 \text { to } 2 \frac{1}{2} \mathrm{ft} \text {. . . . . . . . \$3.50 \$33.00 \$ } \\
& 2 \frac{1}{8} \text { to } 3 \mathrm{ft} \text {. . . . . . . } 4.5040 .00 \\
& \text { horizontalis TraILING JUNIPER } \\
& 15 \text { to } 18 \text { in. spread .... } 3.5033 .00 \\
& 18 \text { to } 24 \text { in. " . . . . . } 400 \quad 42.00 \\
& 2 \text { to } 2 \frac{1}{2} \mathrm{ft} \text {. " } \quad \text {. . . . . } 6.00 \quad 57.00 \\
& \text { douglasi WAUKEGAN JUNIPER } \\
& 8 \text { to } 12 \text { in. spread .... } 2.75 \\
& \text { i2 to } 15 \text { in. " } 3.0 . \text {. . } 3.0027 .00
\end{aligned}
$$

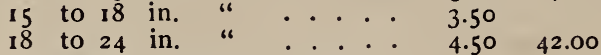

$$
\begin{aligned}
& \text { sabina SAVIN JUNiper } \\
& \text { I } \frac{1}{2} \text { to } 2 \mathrm{ft} \text {. spread . . . . . } 4.50 \quad \mathbf{4 2 . 0 0} \\
& 2 \text { to } 2 \frac{1}{2} \mathrm{ft} \text {. " } \quad . . . \quad \text {. } 5.50 \quad 52.00 \\
& \text { tamariscifolia TAMARI SAVIN } \\
& \text { I to } 1 \frac{1}{2} \mathrm{ft} \text {. spread . . . . } 4.00 \\
& \text { If to } 2 \mathrm{ft} \text { " } \\
& 2 \text { to } 2 \frac{1}{2} \mathrm{ft} \text {. " } \quad \text {. . . . . } 7.50 \\
& \text { virginlana RED CEDAR Nursery grown } \\
& 9 \text { to } 10 \mathrm{ft} \text {. . . . . . } 30.00 \\
& 10 \text { to } 12 \mathrm{ft} . \ldots . . . .35 .00 \\
& 12 \text { to } 30 \mathrm{ft} \text {. . . . } 35 \text { to } 125.00
\end{aligned}
$$

Collected. 10 to $30 \mathrm{ft}$. Prices on application.

Note. Among the above are many very handsome specimens, particularly among the larger plaits, which were moved into the Nursery a few years ago and which will be moved on platforms.

glauca SILVER REDCEDAR

$$
\begin{aligned}
& 4 \text { to } 4^{\frac{1}{2}} \mathrm{ft} \text {. . . . . . } 10.00 \\
& 10 \text { to } 12 \mathrm{ft} \text {. . . . . . } 50.00 \\
& 12 \text { to } 14 \mathrm{ft} \text {. . . . . . . . } 60.00 \\
& \text { kosterl KOSTER'S RED CEDAR } \\
& 12 \text { to } 15 \text { in. spread .... . 3.00 } 27.00 \\
& 15 \text { to } 18 \text { in. " ..... } 4.0036 .00 \\
& 18 \text { to } 24 \mathrm{ln} \text {. " } \quad \text {. . . . . } 5.00 \quad 48.00 \\
& \text { schottl SCHOTT REDCEDAR }
\end{aligned}
$$

4 to $4 \frac{1}{2} \mathrm{ft}$. XX spec. .. 10.00 tripartita Fountain REDCEDAR

Kalmia latifolla Mountain LAUREL

$$
5 \text { ft. } \times 7-8 \text { spec. . . } 75.00
$$

$$
\begin{aligned}
& 15 \text { to } 18 \text { in. . . . . . } 3.00 \quad 27.00 \\
& \text { It to } 2 \mathrm{ft} \text {...... } 3.50 \\
& 2 \text { to } 2 \frac{1}{2} \mathrm{ft} \text {....... } 4.00
\end{aligned}
$$

Leucothoe catesbael Drooping LEUCothoE

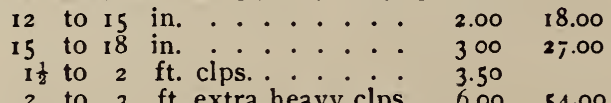

Picea albertiana Alberta SpRUCE

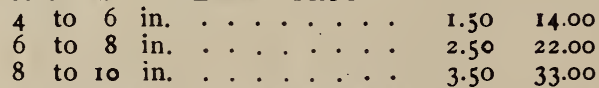

A charming symmetrical evergreen, which grows so slowly that it will stay in scale for many years. 
Each

10

100

Picea canadensis (alba) White or CAT SPRUCE

20 to $24 \mathrm{ft}$. . . . 75 to 100.00

excelsa Norway SPRUCE

15 to 18 in. ...... $\$ 2.00 \$ 1800 \$$

18 to 24 in....... 2.5021 .00

24 to 30 in. . . . . . 3.0027 .00

30 to 36 in. ................ $3.50 \quad 33.00$

36 to 48 in. ........ $4.50 \quad 40.00$

compacta Globe Norway SPRUCE

$3^{\frac{1}{2}}$ to $4 \mathrm{ft} . \times 5^{\frac{1}{2}-6 \frac{1}{2}} \mathrm{ft}$. spread 100.00

extremely fine old specimens

parviformis DWARF Pyramid SPRUCE

6 to 8 ft. $\times 6-7 \mathrm{ft}$. spread

spec. tr. 1920 . . \$75 to \$110.00

remonti REMONT DWARF SPRUCE

2 to 2 ft. ..... I 5.00

6 to $7 \mathrm{ft} \times 6-7 \mathrm{ft}$. . roo to 150.00

Note. Some of our Dwarf Spruce are wonderful specimens, and all of them have been moved recently. For formal notes or for the foreground of Evergreen plantings these plants are admirably adapted.

orlentalis OrIENTAL SpRUCE

6 to ro $\mathrm{ft}$..... 40 to 50.00

pungens COLORADO SPRUCE

14 to $16 \mathrm{ft}$. spec. $\operatorname{tr}$. 192065 to 75.00

I6 to $\mathrm{I} 8 \mathrm{ft}$. spec. $\mathrm{tr}$. 192075 to 90.00

glauca Colorado Blue Spruce

Io to $12 \mathrm{ft}$. tr. $1920 \ldots . .60 .00$

12 to $14 \mathrm{ft}$. tr. $1920 \ldots 75.00$

14 to $16 \mathrm{ft}$. tr. 1920.80 to 90.00

$\mathrm{I} 6$ to $\mathrm{I} 8 \mathrm{ft}$. tr. $1920 \cdot 90$ to 150.00

kosteri Koster Blue SPRUCE

3 to to $\mathrm{ft.} . \ldots 6_{5}$ to 90.00

Io to $I 2 \mathrm{ft} . \ldots . .90$ to 125.00

I 2 to $14 \mathrm{ft}$...... I.25 to 150.00

16 to $18 \mathrm{ft}$. . . . I 150 to 175.00

Pieris (Andromeda) floribunda Mountain Andromeda

15 to 18 in. spread .... 5.00

Pinus cembra Swiss Stone Pine

The Swiss Stone Pine is one of the most beautiful of all pines for formal work. The tree is very slow growing, consequently is important for use as accents where one wishes an accent which will stay in scale many years. Our plants are all beautiful specimens.

8 to il $\mathrm{ft}$. Prices on application

excelsa Himalayan Pine $2 \mathrm{ft} . \times 2 \frac{1}{2} \mathrm{ft} . \ldots 10.00$

montana mughus Mugho or Dwarf Mountain Pine

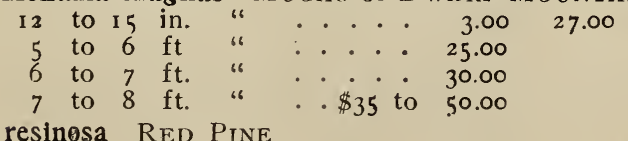

4 to $5 \mathrm{ft}$....... 6.00 
Pinus strobus White Pine

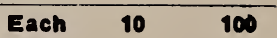

6 to 7 ft. tr.pl. 1920 bushy $\$ 8.00 \$ 75.00 \$$

7 to 8 ft. " " " $10.00 \quad 90.00$

8 to $10 \mathrm{ft}$. " “ "

Io to $15 \mathrm{ft}$. spec. Prices on application

rscudotsuga douglasi Douglas FIR

2 to $2 \frac{1}{2} \mathrm{ft} . \ldots \ldots . . .250 \quad 42.00$

$2 \frac{1}{2}$ to $3 \mathrm{ft}$. ...... $5.50 \quad 51.00$

Rhododendron carolinianum CAROLINA RHODODENDRON

12 to 15 in. B \& B .... 3.0027 .00

15 to 18 in. B \& B ... $3.50 \quad 33.00$

2 to $2 \frac{1}{\mathrm{ft}} \mathrm{B} . \mathrm{B} \& \mathrm{~B} \ldots . . .44 .50 \quad 42.00$

$2 \frac{1}{2}$ to $3 \mathrm{ft}$. B \& B . . . $6.00 \quad 55.00$

Album elegans Large white

$2 \mathrm{t}$ to $3 \mathrm{ft}$......... 12.00

Amphion (F. L. Ames) White center with wide margin $2 \frac{1}{2}$ to $3 \mathrm{ft}$. $\times 3-3 \frac{1}{2} \mathrm{ft}$. spread 25.00

Catawbiense alba White

$$
2 \mathrm{ft} \text {. . . . . } 8.00
$$

Charles Dickens Scarlet early

$2 \mathrm{ft}$....... 8.00

Delicatissimum Blush white

$$
2 \mathrm{ft} \text {....... } 10.00
$$

E. S. Rand Rich crimson $2 \frac{1}{\mathrm{ft}} \mathrm{ft} . . . . .10 .00$

Everestianum Rosy lilac

Flushing

$$
2 \text { ft. ..... } 8.00
$$

$$
2 \frac{1}{8} \mathrm{ft} . \text {. . . . . } 10.00
$$

General Grant Red $2 \frac{1}{\mathrm{f}} \mathrm{ft}$. ...... 10.00

Grandifiorum Clear rose

$$
\begin{aligned}
& 2 \text { to } 2 \frac{1}{2} \mathrm{ft} \text {....... } 10.00
\end{aligned}
$$

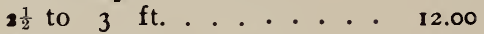

Kettledrum Rich crimson

$$
2 \mathrm{ft} \text {....... } 10.00
$$

Lee's Dark purple

$$
2 \text { ft. . . . . } 8.00
$$$$
2 \frac{1}{2} \mathrm{ft} . . . . . .12 .00
$$

Mrs. Charles S. Sargent Pink

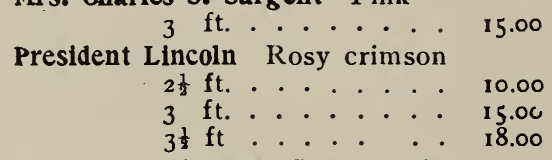

Purpureum elegans Best purple

2 to 2 f $\mathrm{ft}$. ....... 10.00

Roseum elegans Deep rosy pink

$2 \frac{1}{8} \mathrm{ft}$. ....... 10.00

$3 \mathrm{ft} . . . . .215 .00$

laeterirens (wilsonianum) WILSON RHODODENDRON

9 to 12 in. $\times 18-24$ in. . 7.50

18 to 24 in. $\times 2 \frac{1}{8}-3 \mathrm{ft}$. . 12.00 
Each 10
HODODENDRONS

Rhododendron maximum ROSE BAY RHODODENDRONS nursery grown

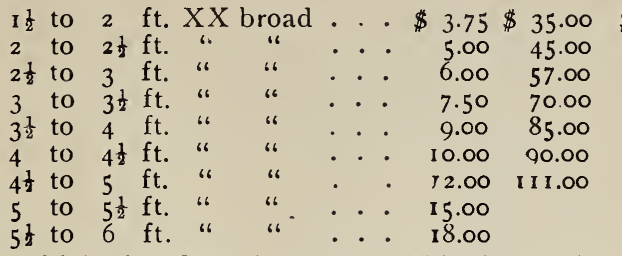

COLLECTED CLUMPS F.O.B. our shipping point in

Pennsylvania in carload lots.
2 to $5 \mathrm{ft}$. mixed clumps at $\$ 500$ per carload
5 to $8 \mathrm{ft}$. XXX broad specimen clumps

Prices on application

We make a specialty of collecting Rhododendron Maximum in carload lots. The plants vary in size from $\mathrm{I}$ to $5 \mathrm{ft}$. From $6_{5}$ to $35^{\circ}$ plants can be put into a car, depending upon the size of the plants. We ship only first class plants.

Taxus canadensis CANADA YEW

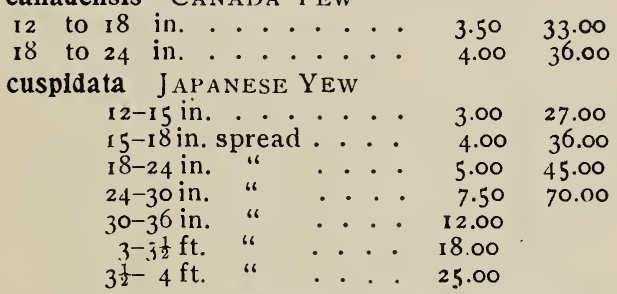

Our Taxus cuspidata are all heavy plants, recently transplanted. We believe there is no finer stock of this indispensable Evergreen in this country.

densa COMPACT DWARF JAPANESE YEW $8-12$ in. spread ...
$12-15$ in. 4.00

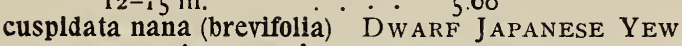

$$
\begin{aligned}
& \text { 9-12 in. spread . . } 350 \quad 30.00 \\
& 18-21 \text { in. " . . } 8.0075 .00 \\
& 21-24 \text { in. " ... } 12.00 \quad 115.00 \\
& 24-30 \text { in. " . . } 18.00 \quad 165.00 \\
& 30-36 \text { in. " } \\
& 36-42 \text { in. " ... } 40.00
\end{aligned}
$$

Thuja occidentalis American ARBor Vitae

$$
\begin{aligned}
& \text { I } 8 \text { to } 24 \text { in. . . . . } 3.0027 .00 \\
& 2 \text { to } 3 \text { ft. . . . . . . } 3.5033 .00 \\
& 3 \text { to } 4 \mathrm{ft} \text {...... } 4.5040 .00 \\
& 4 \text { to } 5 \text { ft. ...... } 6.00 \quad 55.00 \\
& 6 \text { to } 7 \text { ft. spec. . . . . } 10.00 \\
& 7 \text { to } 8 \mathrm{ft} \text { " } \\
& 8 \text { to } 9 \text { ft. " } \quad . \ldots . .15 .00 \\
& 9 \text { to ro ft. " . . . . } 21.00 \\
& \text { II to } 12 \mathrm{ft} \text {. old spec. } 60 \text { to } 75.00
\end{aligned}
$$


Each $10 \quad 100$

Thuya occidentalis buchanani Buchanan Arbor Vitae

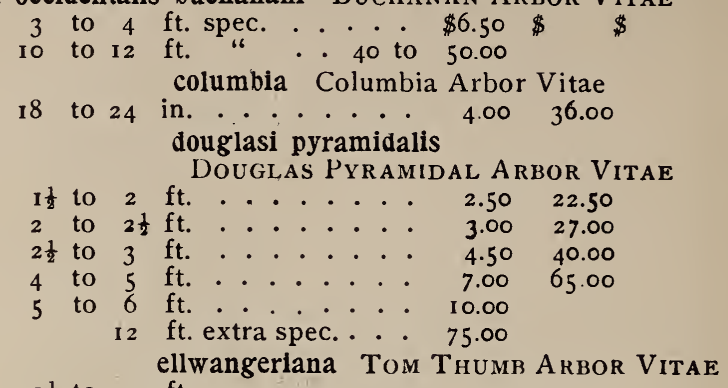

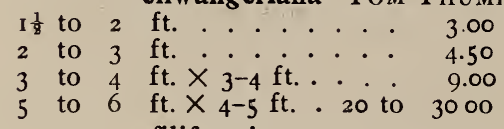
fillformis

Weeping Oriental Arbor Vitae

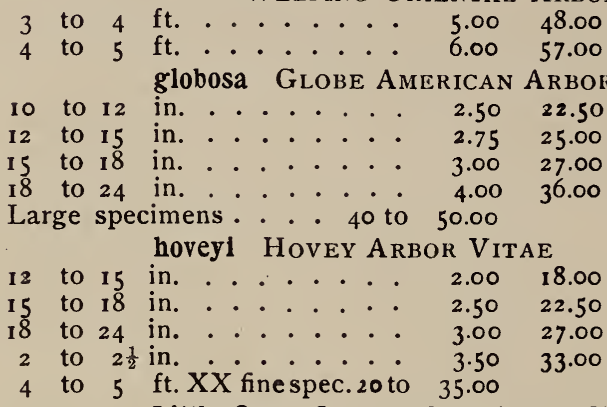

Little Gem LitTle Gem Arbor Vitae

8 to 12 in. spread.... 3.00

12 to 15 in. ..... 4.00

15 to 18 in. ...... 500

lutea George Peabody Arbor Vitae

$1 \frac{1}{2}$ to $2 \mathrm{ft.}$........ $3.50 \quad 33.00$

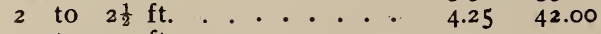

3 to $4 \mathrm{ft.} . \ldots \ldots 750$

5 to $6 \mathrm{ft.}$........ 10.00

plicata Giant Arbor Vitae

12 to 18 in. ...... 4.5042 .00

4 to $5 \mathrm{ft}$........ 12.00

pyramidalis Pyramidal Arbor Vitae

2 to $2 \frac{1}{2} \mathrm{ft} . \ldots . . .24 .00 \quad 36.00$

$2 \frac{1}{8}$ to $3 \mathrm{ft} . \ldots . . .25 .0045 .00$

3 to $3 \frac{1}{2} \mathrm{ft} . \ldots . . .6000000$

$3 \frac{1}{2}$ to $4 \mathrm{ft}$........ $7.00 \quad 68.00$

Queen Victoria

QUeen Victoria ARbor Vitae

12 to 18 in. ...... 3.50 
Thuja occidentalis reldi REID ARBOR VITAE

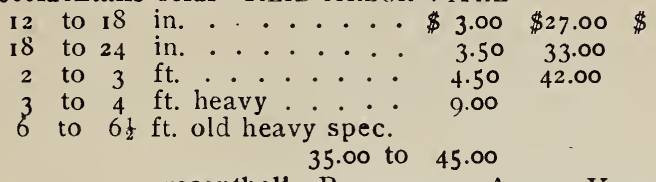

rosenthall Rosenthal ARBOR Vitae

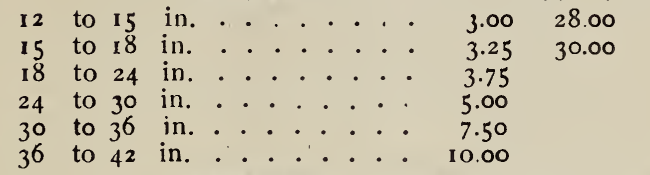

vervaeneana Vervaene Arbor Vitae

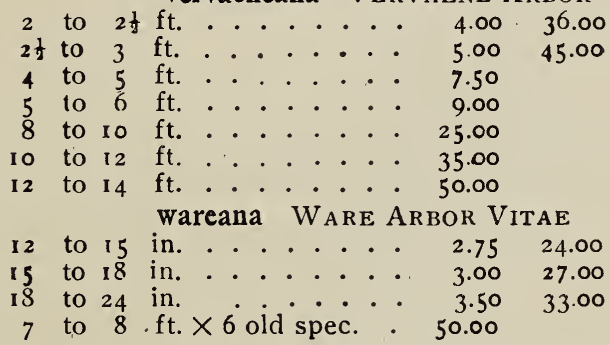

Waxen Golden Akbor Vitae

2 to $2 \frac{1}{2} \mathrm{ft}$. . . $3.00 \quad 27.00$

6 to 7 ft. $\times 7-8 \mathrm{ft}$. $X X X$ spec.

woodwardi 50 to 60.00

Woodward Globe Arbor Vitae

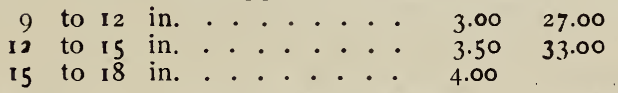

Most of our Arbor Vitaes have been transplanted within the last two years, and are in prime condition for hedges or specimens.

Isuga canadensis AmERICAN HEMLOCK

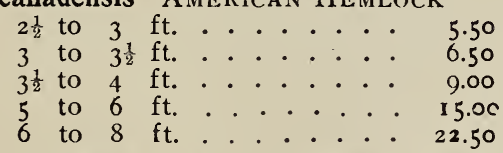

caroliniana CAROLINA HEMLOCK
$2 \frac{1}{2}$ to $3 \mathrm{ft}$...... 5.50
3 to $4 \mathrm{ft.}$..... 7.00
4 to 5 ft. . . . . . 10.00

Our Hemlocks, too, have been transplanted recently and all are beautiful, broad, specimens, which came through last winter unharmed. 


\section{LIST OF POT-GROWN PLANTS}

\section{Which can be shipped and planted at all times}

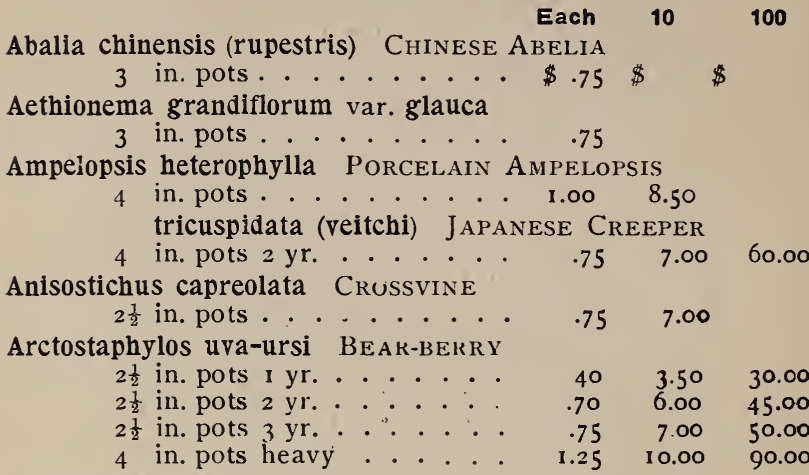

Azalea kaempferi TORCH AzAlEA

5 in. pots ........ $1.50 \quad 12.50$

ledifolia (indica alba) SNow Azalea

4 in. pots ........ 1.50

Hazel Dawson Dawson HYBRID new

12.50

4 in. pots ....... 4.00

indica pink

4 in. pots........ $200 \quad 18.00$

schlippenbachi Royal AzaLEA

4 in. pots....... . $4.50 \quad 42.00$

obtusa klusiana Kurume Azalea

Originated in the city of Kurume, on the Island of Kyashu, Japan, nearly roo years ago, these beautiful plants have been practically unknown in Europe and America until brought to the attention of the public a few years ago by Mr. E. H. Wilson, of the Arnold Arboretum. The plants of this group are of dwarf, compact habit, with small, deep green, glossy, evergreen foliage, and small flowers, borne in great profusion, and covering the plants for many weeks with their fairy clouds of exquisite color. Many of the varieties have flowers known as "hose-inhose," that is, having a petaloid calyx and giving the effect of one corolla set within another.

Kurume Azaleas are hardy on Long Island, New York, and thence south. In the north these plants are of untold value for forcing for winter bloom in conservatory or greenhouse. From a collection of over 200 sorts Japanese experts have selected what they consider the best six varieties. We are now offering for sale plants of these six varieties, raised from cuttings. With one exception the varieties offered have hose-in-hose flowers.

The six varieties referred to are:

TAKASAGO, pure pink, hose-in-hose

AzUMA-KAGAMI, deep pink hose-in-hose

KIRIN, deep rose, shading to silvery rose, hose-in-hose

Plant Bearberry and Scotch Heather near the sea 
KURENO-YUKI, pure white, hose-in-hose

KUMO-NO-NYE, pure salmon, single

KURAI-NO-HIMO, pure carmine, hose-in-hose

$\$ 18.00$ per set of one each of the above plants 4 years old, in 5-inch pots, packed for shipment.

Each $\quad 10 \quad 100$

Berberis verne VERNA BARBERRY

3 in. pots....... \$1.00\$9.00 \$

verruculosa WARTY BARBERRY

3 in. pots ........ $1.50 \quad 13.50$

Bruckenthalia spiculifolia SPIKE HEATH. Flowers pink blooming from June to August. Grows 6 in. high

4 in. pots ......... $1.50 \quad 13.50$

Buddleia davidi Orange-Eye Butterfly Bush

3 in. pots ......... $60 \quad 5.50$

Callicarpa dichotoma Chinese BeAutyberry

3 in. pots . . . . . . $75 \quad 7.00$

Calluna vulgaris SCOTCH HEATHER, and named varieties

Scotch Heather, the "Bonnie Purple Heather" of song and verse, is a lovely, low-growing evergreen shrub, 6 in. to $3 \mathrm{ft}$. in height, of the Heath Family, covered in midsummer with small, bell shaped purple flowers, borne on slender spikes. These flowers stay in good condition for some weeks, and if cut while fresh will hold their color and charm all winter. Honey bees, too, are attracted to Scotch Heather and make from it a honey that is considered very choice. This plant is widely known as invaluable for planting in full sun in sandy soil: it is also most attractive as an edging to beds of Rhododendrons, Laurel, etc., and in Rock Gardens. This little plant gives most satisfaction when planted from pots. Besides the common purple Heather there are many varieties which give variation in the height of plant, color of flowers. and season of bloom. Below we offer a list of varieties, all of which are pot grown, sturdy plants. $2 \frac{1}{2}$ and 3 in. pots

flora plena A double-flowered form of our plain Scotch Bonnie Purple Heather. $2 \frac{1}{3}$ and 3 in. pots var. alba White SCOTCH HEATHER, early blooming, with light green foliage, white flowers, grows 12 to 15 inches. $2 \frac{1}{2}$ and 3 in. pots

var. alba elata TALL White Heather. Late blooming, very tall, straight growth. Foliage soft dark green, flowers white, grows 18 to 24 in. $2 \frac{1}{2}$ and 3 in. pots

var. alba erecta TALL WhITE HEATHER. Late blooming, foliage dark green, flowers white, grows 18 in. $2 \frac{1}{3}$ and 3 in. pots

var. alba hammondi Hammond White Heather. Midseason, tall upright growth, foliage rich deep green, flowers white, grows 18 to 24 in. high. $2 \frac{1}{2}$ and 3 in. pots

var. alba minor Dinakf White Heather. Mid-season tall bushy growth, $15^{-20}$ in. high, foliage very fine light green; flowers white. $2 \frac{1}{3}$ and 3 in. pots

var. alba pilosa Late blooming, tall growth $18-20$ in. high, foliage of soft grayish green, flowers white. $2 \frac{1}{2}$ in. pots

var. alba rigida BRUSH HEATHER. Late, low rigid growth, toliage rich deep green, flowers white. $2 \frac{1}{2}$ and 3 in. pots

For prices see pages $11-12$ 
Calluna vulgaris

var. alba searlii Foliage golden, not very noticeable in winter, nor objectionably tall, grows 18 to 20 inches. $2 \frac{1}{2}$ in. pots

var. alba spicata Tall White Heather. New. Grows 20 to 24 in. high. $2 \frac{1}{2}$ and 3 in. pots

var. alporti ALPORT HEATHER. Late blooming, tall straight grow th to 24 in. foliage deep rich green, turning purple in autumn. Flowers rosy carmine. $2 \frac{1}{2}$ and 3 in. pots

var. argentea Flowers pink, foliage whitish, yellow green. Grows 15 to 18 in. high. $2 \frac{1}{2}$ in. pots

var. aurea Golden foliage and pink flowers, one of the best of those with colored foliage. $2 \frac{1}{2}$ and 3 in. pots

var. compacta Late blooming. Low compact, moss-like growth, 4 to 6 in. high, of bright, rich green. Flowers pale lavender. $2 \frac{1}{2}$ in. pots

var. cuprea Mid-season. Straight medium growth 12 to 15 in. high, foliage bright, almost yellowish green, turning to rich glowing red in autumn. Flowers purple. $2 \frac{1}{2}$ and 3 in. pots

var. hirsuta (tomentosa). Woolly Heather. Midseason. Low compact growth. 4 to 7 in. high, foliage soft gray, flowers purple. $2 \frac{1}{2}$ and 3 in. pots

var. humilis Low growing, with rich green foliage. Flowers, midseason, white. $2 \frac{1}{2}$ and 3 in. pots

var. hypnoides Late blooming. Low-spreading growth, 6 to 12 in. high. Foliage soft deep green, flowers deep pink. $2 \frac{1}{2}$ and 3 in. pots

var. monstrosa Loose growth. Flowers pink. $2 \frac{1}{2}$ in. pots var. rosea Mid-season. Tall straight growing with delicate pink flowers. $2 \frac{1}{2}$ in. pots

var. rubra RED HeATHER. Early blooming, with low spreading growth, 6 to 12 in. high. Foliage soft green turning purple in autumn. Flowers rosy carmine. $2 \frac{1}{2}$ and 3 in. pots

var. tenella Slender Heather. Early blooming. Low growth with slender spikes of dainty lavender flowers. $2 \frac{1}{2}$ and 3 in. pots.

var. variegata Very bright, whitish green foliage, pink flowers, grows 15 to 20 in. high. $2 \frac{1}{2}$ in. pots

Prices on Heather and varieties:

$$
\text { Each } 10 \quad 100
$$

$$
\begin{aligned}
& 2 \frac{1}{8} \text { in. pots . . . . . . } \$ 5.50 \$ 4.50 \quad \$ 39.00 \\
& 3 \text { in. pots ........... } \quad .75 \quad 6.00 \quad 5400
\end{aligned}
$$

Campannnla isophylla ITALIAN BeLLFLower

4 in. pots blue and white. . 1.25

Cerastium biebersteimi TAURUS CERASTIUM

$$
3 \text { in. pots................ } 35
$$

Clematis montana rubens Pink

4 in. pots........ $2.00 \quad 18.00$

Corema comradi Broom Crowberry

$2 \frac{1}{2}$ in. pots . . . . . . . . . $\quad .50 \quad 4.75 \quad 45.00$

Cornus canadensis BUNCHBERRY

$2 \frac{1}{2}$ in. pots......... . . . $50 \quad 4.80$

Plant Bearberry and Scotch Heather near the sea 


\section{Each}

Coronilla emerus SCORPION-SENNA

$$
2 \frac{1}{2} \text { in. pots......... \$1.00\$9.00\$ }
$$

Note: The Cotoneasters are among the most important groups of hardy plants which have recently been brought before the public. All of them have attractive foliage and conspicuous berries. Of those listed below C. adpressa, horizontalis and its variety perpusilla, and C. microphylla are of low-spreading growth, have small glossy, evergreen-like foliage and bright red berries which stay on the shrubs well into the winter. The plants of this group of Cotoneaster are particularly ddaptable for use in rockery, on the edge of low shrubberies or on slopes. C. Dielsiana, divaricata and salicifolia floccosa are of more shrub-like growth, with long graceful branches, glossy leaves and bright red berries. All of these plants are hardy and do well in any good well-drained garden soil, but require plenty of water during the first year after transplanting, and take hold much more satisfactorily when transplanted from pots than from the field.

Cotoneaster adpressa CREEPING COTONEASTER

$$
\begin{aligned}
& 3 \text { yr. } 3 \text { in. pots . . . . I } 65 \text { I } 44.00 \\
& 4 \text { yr. } 4 \text { in. pots..... . } 2.25 \quad 20.00 \\
& \text { dammeri WEEPING OR FLAT COTONEASTER } \\
& 2 \text { yr. } 3 \text { in. pots..... } 1.25 \\
& 3 \text { yr. } 4 \text { in. pots..... } 1.50 \\
& \text { dielsiana elegans }
\end{aligned}
$$

$\begin{array}{lllll}3 \text { yr. } 3 & \text { in. pots . . . . } \quad .85 & 7.50 & 65.00\end{array}$

3 yr. 4 in. pots..... 1.25

horizontalis Rock COTONEASTEK

$3 \mathrm{yr} .3$ in. pots..... 85

3 yr. 4 in. pots...... 1.50

$8.00 \quad 70.00$ var. apiculata

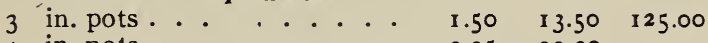

4 in. pots........ 2.252000

perpusilla

3 yr. 3 in. pots..... $1.00 \quad 8.00 \quad 65.00$

3 yr. 4 in. pots ...... $1.50 \quad 13.50$

hupehensis HUPEH COTONEASTER

4 in. pots ....... 1...

microphylla ROcKSPRAY

$\begin{array}{llllll}3 \text { yr. } 3 \text { in. pots } & 85 & 8.00 & 70.00\end{array}$

3 yr. 4 in. pots XX str.... $1.40 \quad 11.50 \quad 100.00$

racemiflora soongarica COREL

Red fruit, very lovely

$\begin{array}{lllll}3 \text { yr. } 4 & \text { in. pots . . . . } & \mathbf{2} .50 & \mathbf{2 2 . 5 0}\end{array}$

salicifolia floccosa Willow LEAF COTONEASTER

3 yr. 3 in. pots...... $1.50 \quad 13.00$

3 yr. 4 in. pots...... $2.00 \quad 18.00$

wilsoni Wilson COTONEASTER

3 yr. 3 in. pots . . . . $1.00 \quad 9.00$

3 yr. 4 in. pots..... $1.50 \quad 13.50$

For prices see pages $11-12$ 
Cytisus beanii BeAN's Bкоом

$\begin{array}{cll}\text { Each } & 10 & 100 \\ \$ 1.00 & \$ & \$ \\ 1.00 & 9.00 & 85.00 \\ 1.00 & 9.00 & \\ .80 & 7.50 & \\ .35 & 3.00 & 25.00 \\ .60 & 5.50 & 50.00\end{array}$

Erica carnea SPRING HeATH

$2 \frac{1}{2}$ in. pots........ . . praecoX WARMINSTER BROOM $2 \frac{1}{2}$ in. pots . . . . . . purgans Provence Broom $3 \frac{1}{2}$ ill. pots . . . . . . . . . $1.00 \quad 9.00$ scoparius Sсотсн ВRоом $2 \frac{1}{2}$ in. pots.... . . . . $\quad .80 \quad 7.50$

Dianthus plumarius CLOVE PINK $2 \frac{1}{2}$ in. pots........ . . . $35 \quad 3.00 \quad 25.00$ Dorycnium hirsutum GRAY FOLIAGE $2 \frac{1}{8}$ in. pots. . . . . . . . . $60 \quad 5.50 \quad 50.00$ $2 \frac{1}{2}$ in. pots........ . . . . . $50 \quad 4.75 \quad 45.00$ 3 in. pots........ . . . $\quad .75 \quad 6.00 \quad 54.00$ stricta CORSICAN HEATH

3 in. pots........ . . . $50 \quad 4.75 \quad 45.00$ tetralix CROSS-LEAF HEATH

$2 \frac{1}{2}$ in. pots......... . . $450 \quad 4.75 \quad 45.00$ vagans CORNISH HEATH

3 in. pots........ . . . . $75 \quad 6.00 \quad 54.00$ Euonymus radicans acutus SHARPLEAF W INTERCREEPER

3 in. pots 3 yr. XX strong . $\quad .75 \quad 6.00$ colorata New

3 in. pots........... $\quad .80 \quad 7.50 \quad 72.00$ kewensis BABY WINTERCREEPER

3 in. pots........... $\begin{array}{llll} & 75 & 6.50 & 55.00\end{array}$ var. minimus

Prostrate Baby Wintercreeper

3 in. pots........ 1.009 .00

Genista pilosa Silkyleaf Вкоом

$2 \frac{1}{2}$ in. pots....... 1.00

Gypsophila repens CREEPING GYPSOPHILA

2 in. pots........ $30 \quad 2.50$

Hedera helix ENGLISH IVY

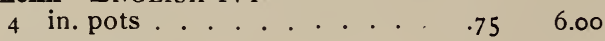

Helwingia japonica

3 in. pots....... 1. 1.00 8.00

Helianthemum SUN ROSE, and named varieties

2 in. pots............ $75 \quad 7.00 \quad 60.00$ alyssoides No. 16231

appeninum No. 15448

chamaecistus No. 4667-2 Single, orange pink stramineum No. 743-I

Clear, lemon yellow flower polifolium No. 16234 variabile No. 16236

vulgari No. 15451 Single, white 


$$
\text { Each } 10
$$

Hypericum buckleyi Mountain ST. Johnswort

$2 \frac{1}{2}$ in. pots........ $\$ .60 \$ 5.50 \$$

calycinum ROSE OF SHARON

$2 \frac{1}{2}$ in. pots........... $40 \quad 3.00$

Iberis sempervirens HARDY EVERGREEN CANDYTUFT

2 in. pots . . . . . . . . $25 \quad 2.00 \quad 16.00$

var. Little Gem Compact Evergreen Candytuft

2 in. pots . . . . . . . $35 \quad 3.00 \quad 20.00$

tenoreana Tenore CANDytuft

$2 \frac{1}{2}$ in. pots............. $40 \quad 3.60$

Kolkwitzia amabilis BEAUTY BUSH

3 in. pots........ $2.00 \quad 18.00$

4 in. pots....... 2.5021 .00

Leiophyllum buxifolium SANDMYRTLE

5 in. pots.............. $1.25 \quad \mathbf{1 2} .00$

prostratum Box SANDMYRTLE

3 in. pots............ I.25 12.00

Leucocrinum montanum STAR LILY

$2 \frac{1}{2}$ in. pots........ . . . $60 \quad 5.00$

Linnaea Borealis Americana Twinflower

$2 \frac{1}{2}$ in. pots.......... $50 \quad 4.75 \quad 45.00$

Lithospermum fruticosum (prostratum) SHRUBBY CROMWELL $2 \frac{1}{2}$ in. pots........ . . $75 \quad 7.00$

Lonicera heckrottl EvERBLOOMING HONEYSUCKLE

3 in. pots......... $1.00 \quad 9.00$

henryi Henry HoNeysuckle New

3 in. pots............. $75 \quad 6.00$ nitida

4 in. pots ....... $1.00 \quad 9.00$

plleata PRIVET HoNEYSUCKLE

This Honeysuckle, also, is evergreen. The growth of this shrub is somewhat stiff, and spreading, the foliage $\frac{1}{2}$ to 2 inch long, rather box-like, and bright shining green. While still a small plant L. pileata is covered with small yellow flowers which produce in early autumn beautiful transparent berries of clear light purple. Like L. nitida this shrub does not always survive the severe winters of this climate; but in southern New England and south and west it is one of the most useful and beautiful of the new shrubs. It will serve as a specimen shrub in the garden, a shrub for rockgardens, or as a low, wide-spreading hedge.

4 in. pots....... $1.00 \quad 7.50$

Nepeta mussini

2 in. pots........ $\quad .30 \quad 2.50 \quad 18.00$

Pachistlma canbyi CanBY PaChistrma

$2 \frac{1}{4}$ in. pots $3 \mathrm{yr}$...... $70 \quad 5.50$

Pachysandra terminalis JAPANESE PACHYSANDRA

2 in. pots......... $\quad .25 \quad 2.00 \quad 14.00$

$2 \frac{1}{2}$ in. pots......... $\quad .35 \quad 2.50 \quad 16.00$

Papaver Gerald Perry Apricot pink

3 in. pots....... 1.00 


\section{Each $10 \quad 100$}

Papaver Lord Lambourne New, bright scarlet 3 in. pots........ \$I.50 \$ \$ Mahoney Queen Carmine purple 3 in. pots....... 1.00 Mrs. Perry Salmon-rose 3 in. pots......... . . $\quad .75 \quad 7.00$ Princess Eva Crimson

3 in. pots........ I.00

Princess Victoria Louise Soft salmon-rose

3 in. pots....... $1.00 \quad 9.00$

4 in. pots......... $1.50 \quad 1350$

Royal Scarlet Red with dark center

3 in. pots....... $1.00 \quad 9.00$

Phlox subulata alba WhiTe Moss

$2 \frac{1}{2}$ in pots.............. $25 \quad 2.50 \quad 21.0$

var. lilacina Lilic Moss

2 in. pots............ $30 \quad 2.50 \quad 21.00$

subulata var. G. F. Wilson LAVENDER MOSS

$2 \frac{1}{2}$ in. pots.... $.2 .30 \quad 2.50 \quad 21.00$

vivid PINK MOss 30 . 2.50 (21.00

Plumbago larpente

$2 \frac{1}{2}$ in. pots........ $\quad .30 \quad 2.50 \quad 21.00$

3 in. pots...... $1.00 \quad 6.00$

4 in. pots............ $1.50 \quad 7.50$

Potentilla tridentata Wineleaf Cinquefoil.

$2 \frac{1}{2}$ in. pots XX strong ... $\quad .40 \quad 3.50 \quad 30.00$

Pyracantha coccinea SCARLET THORN

4 in. pots ro-1 2 in. . . . 2.00

Rosa Alberic Barbier
4 in. pots
1.2510 .00

American Pillar Climber of strong growth with rich glossy foliage and huye clusters of large, cherry-colored flowers

$$
4 \text { in. pots . . . . . . . } 75 \quad 7.00
$$

bella SOlitaky ROSE

3 in. pots....... 2.00

Betty Blossom Dawson hybricl, climbing rose, glossy foliage and large delicate pink flowers, early, flowering just before Dr. Van Fleet

3 in. pots..... 1.75

4 in. pots....... 2.00

Blanc de Coubert Immense fragrant, pure white flowers 3 in. pots ....... 1.00

Crimson Rambler

4 in. pots......... . . . . $75 \quad 6.00$

Cynthia E. Hollis Dawson hybrid Pale double pink

4 in. pots...... $4.60 \quad 18.00$

Daybreak A Dawson hybrid. Climber with glossy foliage and large clusters of single deep salmon pink flowers in July

4 in. pots........ $1.00 \quad 7.50$

Dorothy Perkins Climber with glossy foliage and clusters of late-blooming, deep-pink, double flowers

4 in. pots ....... $\quad .75 \quad 6.00$ 


Each $10 \quad 100$

Rosa Dr. Van Fleet Strong growing climber with glossy foliage and large double shell pink flowers in early July

4 in. pots........\$1.15 \$ \$

ecae ECA ROSE For June shipment only

4 in. pots...... 2. 2.50

Excelsa Climbing wichuraiana hybrid bearing clusters of double brilliant red flowers late in season

4 in. pots....... 1.00

Farquhar-Dawson Hybrid climber. Double pink

4 in. pots.......... $1.25 \quad 12.00$

Goldfinch YeLLOW RAMBLER

4 in. pots.......... I.50 13.00

Harrison's Yellow Old-fashioned yellow Rose

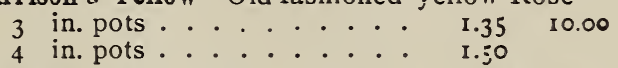

Helenae HELEN Rose. Shrub with slender branches and large clusters of pure white fragrant flowers. Considered by the Arnold Arboretum one of the handsomest of all roses brought from China by Mr. Wilson

3 in. pots........ 2.00

hibernica grovesi Irish Rose. Single flowered pink rose closely related to the Scotch Rose

3 in. pots ....... 1.25

4 in. pots ......... 1.50

hugonis Father Hugo's Rose. An upright rose with stems covered in early spring witn single clear yellow flowers before the foliage appears

$2 \frac{1}{2}$ in. pots............ 1.25 I0.00 90.00

4 in. pots....... $2.00 \quad 17.50$

Lady Duncan A Dawson hybrid, semi-climber, with rich green rugosa-like foliage, and large clear salmon-pink flowers, blooming in late June. Absolutely free from injurious pests

3 in. pots ........... $1.50 \quad 13.50$

Lady Gay Pink climber much like Dorothy Perkins
4 in. pots . . . . . . $.75 \quad 6.00$

Mme. Plantler Pure white, very free bloomer

3 in. pots................. 1.25 10.00

4 in. pots....... $1.50 \quad 12.50$

micrantha

3 in. pots....... $1.75 \quad 16.00$

4 in. pots........ $2.50 \quad 22.00$

moyesil Moyes Rose. Tall shrub of loose growth, with large pointed foliage and small deep red flowers, followed by long orange-red fruits. Introduced from China by E. H. Wilson

3 in pots . . . . 1.75

multibracteata An attractive plant with small leaves and small flowers in cluster, clear pale pink, single

3 in. pots ...... 2.00 


Each $10 \quad 100$

Rosa multiflora catheyensis CATHAY ROSE. The pink multiflora from China

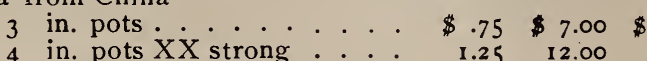

omiensis Mount OMei Rose

3 in. pots....... 2.00

Pauline Dawson A Dawson hybrid climber or pillar rose of good foliage and large single deep pink flowers

3 in. pots........ 1.2510 .00

4 in. pots.......... $1.50 \quad 13.00$

Penzance hybrids Bush Roses, bybrids of the popular Sweet Briar, having fragrant pink flowers

3 in. pots..... . $1.25 \quad 12.00$

4 in. pots ........ $1.50 \quad 13.50$

Persian Yellow Double

3 in. pots....... $1.25 \quad 10.00$

4 in. pots........ . $1.50 \quad 12.50$

Purity Pure white, climbing

3 in. pots........ $1.25 \quad 12.50$

4 in. pots........ $1.50 \quad 12.50$

rugosa repens alba Climbing or creeping white-flowered rugosa hybrid, with glossy foliage and large star-shaped white flowers

3 in. pots........ 1.2510 .00

4 in. pots .......... 1.50

Sargent Dawson hybrid, semi-double pink

4 in. pots ....... I. 1.50

Seashell Dawson hybrid. Climber which has glossy foliage and large clusters of large semi double pink flowers, blooming in July

4 in. pots....... 1.50

Silver Moon Climber with glossy rich foliage and large single cream white flowers, blooming in July

4 in. pots....... $1.00 \quad 7.50$

spinosissima Scotch Briar

3 in. pots ........ $1.25 \quad 10.00$

4 in. pots.......... $1.75 \quad 15.00$

var. altaica Altai Rose cream white

3 in. pots .......... $1.75 \quad 16.00$

4 in. pots . . . . . $2.00 \quad 18.00$

var. cestiflora single sulphur yellow

3 in. pots . . . . . . $175 \quad 16.00$

4 in. pots... . . . . 2.0018 .00

var. Dominie Sampson semi-double, soft pink

3 in. pots........ $1.75 \quad 16.00$

4 in. pots . . . . . . 2.00

var. Fulgens

3 in. pots... ..... $1.75 \quad 16.00$

4 in. pots....... 2.00 . .

var. Iris double white

3 in. pots........ 1.75 16.00

4 in. pots ......... $2.00 \quad 18.00$ 


$$
\text { Each } 10
$$

Rosa spinosissima var. Jupiter single, bright pink

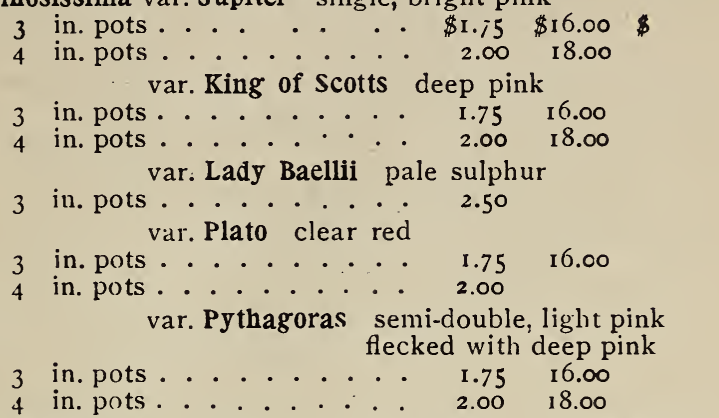

Tausendschon Climber. Good foliage, flowers large, shell pink fading to white. Late bloomer. July

4 in. pots....... $.75 \quad 6.00$

William C. Egan A Dawson hybrid, climber, with good foliage and large very double pink flowers. Late June

$$
4 \text { in. pots........... } 1.007 .50
$$

xanthina Korean Rose, single. A bush rose, new, from northern China, with yellow flowers

4 in. pots...... 2.50

Korean Rose, double vellow

4 in. pots...... 2.50

We have also a large collection of field grown Roses

Sedum acre Goldmoss

$2 \frac{1}{2}$ in. pots........ . . . . $30 \quad 2.50 \quad 21.00$

var. sexangulare HEXAGON STONECROP

$2 \frac{1}{2}$ in. pots......... $\quad .35 \quad 3.00 \quad 24.00$

dasyphyllum LEAFY STONECROP

$2 \frac{1}{2}$ in. pots.............. $40 \quad 3.60 \quad 33.00$

hispanicum SPANISH STONECROP gray foliage

$2 \frac{1}{2}$ in. pots ....... . . $30 \quad 2.50$

reflexum JENNEY STONECROP

$2 \frac{1}{2}$ in. pots.............. $40 \quad 3.60$

sarmentosum STRINGY STONECROP

$2 \frac{1}{2}$ in. pots.............. $30 \quad 2.50 \quad 21.00$

sieboldii Siebold STONECROP

2 in. pots..... .. $\quad .35$

Silene maritima SEa Catchfly

$=$ in. pots............. $30 \quad 2.50 \quad 21.00$

Thymus serpyllum MOTHER-OF-THYME

$2 \frac{1}{2}$ in. pots......... . . . $30 \quad 2.50 \quad 21.00$

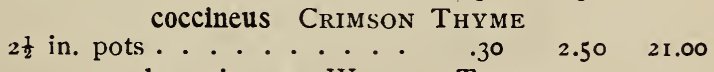

$2 \frac{1}{2}$ in. pots................ $30 \quad 2.50 \quad 21.00$

Vaccineum vitis-idaea minor MOUNTAIN CRANBERRY

$3 \frac{1}{8}$ in. pots heavy ...... $\quad .85 \quad 6.00 \quad 54.00$ 
Veronica rupestris Rock SPEEDwell

Each $10 \quad 100$

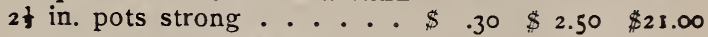
var. rosea

$2 \frac{1}{2}$ in. pots........ . . $35 \quad 3.00 \quad 24.00$

Vinca alba, 2 years White Common Periwinkie

$2 \frac{1}{2}$ in. pots........ . . . $40 \quad 3.50 \quad 33.00$ minor 2 years CoMmon PERIwinkLe

$2 \frac{1}{8}$ in. pots . . . . . . . . . $\begin{array}{llll}.25 & 2.00 & 15.00\end{array}$

Viola Jersey Gem

3 in. pots....... . . . . $35 \quad 3.30$ 


\section{TREES, SHRUBS AND VINES}

Acanthopanax pentaphyllum (Aralia) FiveleAF ARALIA
2 to $3 \mathrm{ft}$.
$\$ .75 \$ 6.00 \$$

Acer ginnale AMUR MAPLE

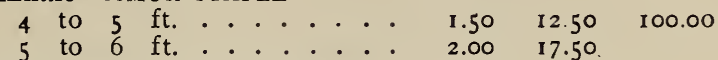

platanoides NorWAY MAPLE

I 4 to 18 ft. 4 to 6 in. cal. . .

$\$ 25$ to 50.00

Actinidia arguta Bower Actinidia

2 to 3 ft. $5 \mathrm{yr}$. XX strong $2.00 \quad 18.00$

This is one of the very best vines, for quick growth, for clean luxurious fcliage, and for growing in shade.

Ampelopsis quinquefolia VIRGINiA CREEPER

Aristolachia sipho Dutchman's PiPE

$$
3 \text { yr. .......... } 60 \quad 4.50 \quad 30.00
$$

large specimens . . 3.00

Aronia melanocarpa (nigra) BLACK CHOKEBERRY

2 to 3 ft. ............ 750.00

Azalea arborescens SiveEt AzALEA

I to $\mathrm{I} \frac{1}{2} \mathrm{ft}$. . . . . 2 $2.50 \quad 22.50$

2 to $2 \frac{1}{2} \mathrm{ft}$. bushy .... $3.50 \quad 33.00$

$2 \frac{1}{2}$ to $3 \mathrm{ft}$. bushy .... $4.50 \quad 42.00$

dahuricum SIBERIAN Azalea

2 to $2 \frac{1}{2} \mathrm{ft}$. B \& B . . . 6.00

japonica (mollis) JAPANESE AZALEA

I2 to 15 in. ..... 3.0027 .00

I5 to 18 in. ..... 3.5033 .00

18 to 24 in. . . . . . 4.5042 .00

kaempferi Torch Azalea

I5 to 18 in. B \& B ... $4.50 \quad 42.00$

I $\frac{1}{2}$ to 2 ft. B \& B .... $5.50 \quad 54.00$

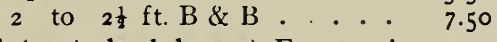

lutea (calendulaceae) Flame Azalea

$\mathrm{I} \frac{1}{2}$ to $2 \mathrm{ft}$. B \& B .... 3.00

2 to $2 \frac{1}{2} \mathrm{ft}$. B \& B.... . 4.00

mucronulatum MONGOLIAN AzALEA

12 to 15 in. . . . . 3.50

I5 to 18 in. ..... 4.00

I $\frac{1}{2}$ to $2 \mathrm{ft}$..... 5.00

poukhanensis KOREAN AzalEa

Io to 12 in. bushy .... 3.50

12 to 15 in. ...... 4.00

15 to 18 in...... 5.00

18 to 24 in. ......... 6.00

rosea Downy Pinxterbloom

2 to $3 \mathrm{ft}$. . 36.00

large spec. clumps $5-7 \mathrm{ft}$. 36 to 8.00

vaseyi Pinkshell Azalea

I5 to 18 in. ..... 3.50

I $\frac{1}{2}$ to $2 \mathrm{ft}$....... 4.50

viscosa Sivamp Azalea

$1 \frac{1}{2}$ to $2 \mathrm{ft}$......... $3.00 \quad 27.00$

2 to $2 \frac{1}{2} \mathrm{ft} \ldots \ldots . .33 .50$

$2 \frac{1}{2}$ to $3 \mathrm{ft}$....... $4.50 \quad 42.00$

For prices see pages $11-12$ 
Berberis thunbergi JAPANESE BARBERRY

Each $10 \quad 100$

$$
\begin{aligned}
& \text { I } 2 \text { to } 15 \text { in. . . . . . . } \$ .25 \$ 2.25 \$ 15.00 \\
& 15 \text { to } 18 \text { in ........... } 35 \text { 3.30 } 21.00 \\
& \mathrm{I} \frac{1}{2} \text { to } 2 \mathrm{ft} \text {. . . . . . . . } \quad .40 \quad 3.50 \quad 24.00
\end{aligned}
$$

Carpinus caroliniana AMERICAN HORNBEAMI

$$
5 \text { to } 6 \mathrm{ft} \text {........ } 4.00 \quad 36.00
$$

Celastrus articulatus AmericAN BitTersweEt

$$
3 \text { to } 4 \mathrm{ft} \text {. extra bushy } \cdots \quad .90 \quad 7.50 \quad 55.00
$$

Chionanthus virginica White Fringetree

$$
\begin{aligned}
& 4 \text { to } 5 \mathrm{ft} \text {. XX bushy spec. } 2.00 \quad \mathbf{1} 8.00
\end{aligned}
$$

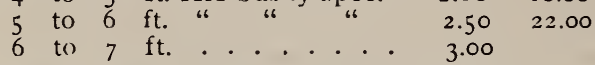

Clematis paniculata Siweet Autumn Clematis

$$
3 \text { yr. strong. ... } 60
$$

Clethra alnifolia Summersweet

$$
\text { I } \frac{1}{2} \text { to } 2 \mathrm{ft} \text {. . . . . . . . } 45 \quad 4.00
$$

2 to $3 \mathrm{ft}$. bushy .... $\quad .50 \quad 4.50$

Cornus amomum (sericea) SILKY DOGWOOD

$$
\begin{aligned}
& 2 \text { to } 3 \mathrm{ft} \text {. . . . . . . . . . } 50 \text { } 5.00 \\
& 3 \text { to } 4 \text { ft. . . . . . . . . } 75 \text {. } 6.00
\end{aligned}
$$

florida FLOWERING DOGWOOD

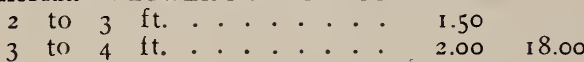

$$
\begin{aligned}
& 4 \text { to } 5 \text { it. } . . . . . .3 .3 .00 \\
& \text { rubra RED FLOWERING DOGWOOD }
\end{aligned}
$$

2 to $3 \mathrm{ft}$. . . . . . 5.0048 .00

3 to 4 ft. . . . . . $7.50 \quad 72.00$

paniculata GRAY DoGwoOD

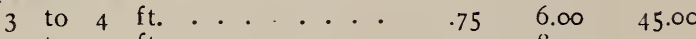

$$
\begin{aligned}
& 4 \text { to } 5 \text { ft. . . . . . . . . } 1.00 \quad 8.00 \\
& 5 \text { to } 6 \mathrm{ft} \text {. . . . . . } 1.25 \quad 9.00
\end{aligned}
$$

stolonifera lutea Yellow BARKeD DOgwood

$$
3 \text { to } 4 \mathrm{ft} \text {. . . . . . . 60 } 5.00
$$

Cotoneaster francheti FRANCHET COTONEASTER

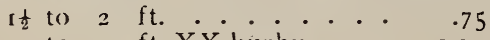

2 to $3 \mathrm{ft}$. XX bushy ... 100 rotundifolia (Wheeler's) ROUNDLEAF COTONEASTER

I5 to Is in. ...... . . . 75

2 to $3 \mathrm{ft}$......... 1.00

Crataegus oxyacantha splendens

Paul's Double Scarlet Hawthorn

$$
3 \text { to } 4 \mathrm{ft} \text {. . . . } 3.50
$$

Cydonia japonica Elowering QUince

I5 to 18 in. . . . . . . . . $75 \quad 6.00 \quad 50.00$

Euonymus alatus Winged EuONyMus

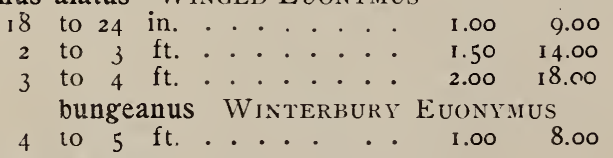

Forsythia intermedia BORDER Forsythia primulina Primkose Forsythia

$\begin{array}{lllllll}2 & \text { to } & 3 & \mathrm{ft} & \ldots & \ldots & 1.00 \\ 3 & \text { to } & 4 & \mathrm{ft} & \ldots & \ldots & \ldots\end{array}$

Plant Bearberry and Scotch Heather near the sea 
Forsythia europaea Albanian ForsythiA

Each $10 \quad 100$

2 to $3 \mathrm{ft}$....... \$1.25 \$ \$

spectabilis SHOwy BORDER FORSYTHIA

2 to $3 \mathrm{ft} . \ldots . . . .1 .25$

suspensa WeEPING Forsythia

2 to $3 \mathrm{ft}$........ $50 \quad 4.50$

fortunei Fortune Forsythia

2 to $3 \mathrm{ft}$......... $50 \quad 4.00$

$310 \quad 4$ ft. .......... $60 \quad 5.00$

viridissima GreENSTEM Forsythia

3 to $4 \mathrm{ft}$. . . . . . . $60 \quad 5.50$

Hydrangea arborescens grandiflora SioOTH HYDRANGEA

$\mathrm{I} \frac{1}{2}$ to $2 \mathrm{ft}$.......... $60 \quad 5.00$

paniculata grandiflora PEEHEE HyDRANGEA

I 8 to 24 in. ......... .60 5.50 45.00

Hypericum aureum GOLDEx ST. JOHN's WORT

2 to $3 \mathrm{ft} . \ldots . . . .60 \quad 5.00$

Ilex verticillata COMMON WINTERBERRY

2 to $3 \mathrm{ft} . \ldots . \cdots \quad 1.00 \quad 9.00$

3 to $4 \mathrm{ft} . \ldots . . . .5130 \quad 13.50$

Ligustrum amurense AiUr River Privet

$\mathrm{I} \frac{1}{2}$ to $2 \mathrm{ft}$. . . . . . . . . $\begin{array}{llll} & 35 & 2.70 & \mathbf{1} 8.00\end{array}$

2 to 3 ft. . . . . . . . $40 \quad 3.00 \quad 24.00$

A hardy Privet with the habit of California Prive

ibota IBota PRIVET

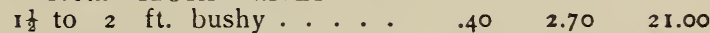

2 to 3 ft. ........ $45 \quad 3.00 \quad 24.00$

3 to $4 \mathrm{ft}$........... $60 \quad 5.00 \quad 40.00$

regelianum REgeL PRIVET

I 8 to 24 in. ......... $50 \quad 4.00$

$2 \frac{1}{3}$ to $3 \mathrm{ft}$............. $60 \quad 5.40$

ovalifolium California PRIVET

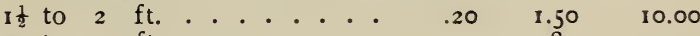

2 to 3 ft. . . . . . . . . $\begin{array}{llll}.25 & 1.80 & 15.00\end{array}$

3 to $4 \mathrm{ft} . \ldots . . . . .35 \quad 2.70 \quad 24.00$

Lonicera japonica halleana HALL JAPANESE HONEYSUCKLE

$$
\begin{array}{rrr}
3 \text { yrs. heavy . * : } & .60 & 4.80 \\
4 \text { yrs. XX heavy : * } & 1.00 & 9.00
\end{array}
$$

korolkowi floribunda

Broad Blueleaf Honeysuckle

2 to 3 ft. ........... 1.25 10.00

morrowl BROAD BLUE-LEAF HONEYSUCKLE

2 to $3 \mathrm{ft} . \ldots . . .60 \quad 4.80$

tatarica alba White Tatakian Honeysuckle

4 to $5 \mathrm{ft}$......... 75 6.50

Thibetica Tibetax HoNeysuckle

12 to 15 in. . . . . . 1.009 .00

Malus arnoldiana ARNOLD CRAB

2 to $3 \mathrm{ft} . \ldots . . .400$

coronaris WILD SweET CRAB

3 to $4 \mathrm{ft}$. . . . . 4.00

floribunda JAPANESE FloweriNG CRAB

2 to $3 \mathrm{ft}$....... 3.00

3 to $4 \mathrm{ft}$...... 4.00 
Malus floribunda atrosanguinea CARMINE $C_{R A B}$

\section{Each
$\$ 4 C_{R A B}$
$\$ 4.00 \$$}

4 to $5 \mathrm{ft} . \ldots \ldots+\$ 4.00 \$ \$$

halliana parkmanni PARKMAN CRAB

3 to $4 \mathrm{ft}$. tr. pl. I92 I . . 4.00

ioensis plena BECHTEL CRAB

3 to $4 \mathrm{ft}$........ 3.00 ,

4 to $5 \mathrm{ft} . \ldots . . . .4 .00$

neidswetzkyana REDveIN CRAB

2 to $3 \mathrm{fl}$....... 2.00 I 8.00

sargenti SARGENT CRAB

2 to $3 \mathrm{ft}$...... 3.00

3 to $3 \frac{1}{2} \mathrm{ft} . \ldots . . . .500$

$3 \frac{1}{8}$ to $4 \mathrm{ft}$....... 7.50

sieboldi calocarpa Toringo $\mathrm{C}_{\mathrm{RAB}}$

spectabilis $4 \mathrm{ft}$. . . . 5.00

pectabilis CHINESE FLOWERING CRAB

var. riversi rosea plena

Double Pink Chinese Flowering Crab

4 to $5 \mathrm{ft}$...... 6.00

theifera TEA CRAB

2 to $3 \mathrm{ft}$. B \& B ... 3.50

4 to 5 ft. B \& B.... 5.00

5 to 6 ft. B \& B . . . 6.00

6 to $7 \mathrm{ft}$. B \& B .... 9.00

toringoides CUTLEAF CRAB

2 to $3 \mathrm{ft}$....... 3.00

Myrica carolinensis NORTHERN BAYBERRY

I5 to 18 in. bushy .... . . . $50 \quad 5.50 \quad 50.00$

Philadelphus coronarius SwEet MOCK ORANGe
3 to $4 \mathrm{ft}$........ . . 60 4.50

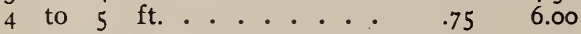
falconeri StaR Mock Orange
3 to $4 \mathrm{ft}$....... .75
grandiflorus Big SCENTLESS MOCK ORANGE
2 to $3 \mathrm{ft}$....... 50 . $4: 50$
satsumanus SATSUMI MOCK ORANGE
3 to 4 ft. ......... 1.00 9.00
4 to 5 ft. . . . . . . . $1.25 \quad 10.00$ splendens
3 to $4 \mathrm{ft}$. . . . . . . . $\quad .75$
Virginal
I 8 to 24 in. . . . . . 1.009 .00
2 to 3 ft. . . . . . . I.25 10.00

Photinla villosa Deciduous Photinia

2 to $3 \mathrm{ft}$. . . . . . $2.75 \quad 25.00$

Potentilla fruticosa parvifolia

PuRdom's Deep Yellow Cinquefoil

I5 to 18 in. Purdomi
var. purdomil

I8 to 24 in. . . . . . I.00 9.00

24 to 30 in......... $1.50 \quad 13.50$

The white and yellow Potentillas are charming shrubs

Plant Bearberry and Scotch Heather near the sea 
of low habit. Their arching branches are covered with delicate divided leaves, and small single flowers, like tiny roses, continuing to bloom from early spring until frost. As a low shrub in the foreground of shrubbery or for the rockery these shrubs are invaluable.

Prunus serrulata sachalinensis (SARGENT) YAMA CHERRY

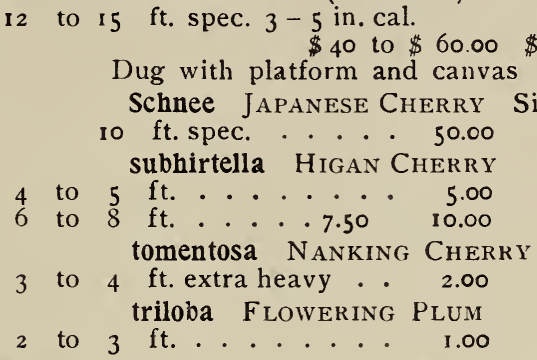

Rhodotypos kerrioides JELBEAD

$$
2 \text { to } 3 \mathrm{ft} \text {........ } 60 \text {. } 60 \text { 5.00 } 48.00
$$

Rosa Alberic Barbier Cream white

$$
3 \text { to } 4 \text { ft. . . . . . . . . } 1.25 \quad 12.00
$$

American Pillar Climber of strong growth with rich glossy foliage and huge clusters of large, cherry-colored flowers

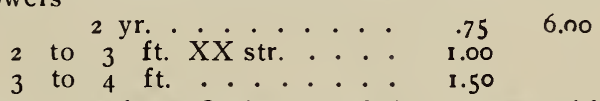

Blanc Double de Coubert Hybrid Rugosa with strong growth, rich foliage, and pure double white flowers

$$
2 \text { to } 3 \mathrm{ft} \text {......... } 1.50 \quad 13.50
$$

Christine Wright Climbing Pink American Beauty

$$
18 \text { to } 24 \text { in. ...... } 1.50 \text { 13.50 }
$$

Crimson Rambler Old fashioned climbing rose with rich crimson semi double flowers in late June and early July.

$$
2 \text { to } 3 \mathrm{ft} \text {........... } 75 \text { } 6.00
$$

Daybreak A Dawson hybrid. A climber with glossy foliage and large clusters of single deep salmon pink flowers in July

$$
\begin{aligned}
& \begin{array}{lllll}
3 \text { yr. . . . . . . } & .75 & 6.00 & 50.00
\end{array} \\
& 2 \text { to } 3 \mathrm{ft} \text {. . . . . . } 1.00 \quad 9.00
\end{aligned}
$$

Dorothy Perkins Bright Pink Rambler

$$
3 \text { yr. strong..... . . . . } \quad 75 \quad 6.00 \quad 50.00
$$

Dr. Van Fleet Strong growing climber with glossy foliage and large double shell pink flowers in early July
3 to
$4 \mathrm{ft}$.
1.50

Excelsa Climbing wichuraiana hybrid bearing clusters of double brilliant red flowers late in season

$$
2 \text { yr. strong ..... } \quad .75 \quad 6.00
$$

2 to 3 ft. XX strong . . . $1.00 \quad 9.00$

3 to $4 \mathrm{ft}$. XXX strong.. $1.25 \quad 10.00$

Gruss au Tepletz Red Hybrid Tea

2 yr. strong ..... $1.00 \quad 9.00$

Harrison's Yellow Old-fashioned yellow Rose

2 to 3 ft. 3 yr. strong .. 1.25 


\section{Each $10 \quad 100$}

Rosa Hiawatha Climber, single scarlet flowers. white center
2 to $3 \mathrm{ft}$
ft. ...... \$ $\$ .75$
$\$ 6.00 \$$
3 to
I.00 9.00

Lady Gay Pink climber much like Dorothy Perkins

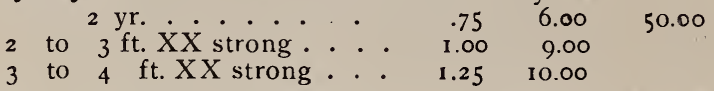

lucida Virginia Rose A wild rose bush, with single pink flowers

2 to $2 \frac{1}{2} \mathrm{ft}$. . . . . . . . $55 \quad 4.50$

alba $A$ white bush rose

I5 to 18 in. ........ $50 \quad 4.50$

Minnie Dawson Dawson hybrid. Rambler of the Dawson habit, the flowers small double white borne in large clusters, early in the season. The Dawson and Minnie Dawson are the earli -st to bloom of all climbers, flowering in our vicinity sometimes in late May, always in early June
3 yr.
$\begin{array}{rrr}1.50 & 12.50\end{array}$
3 to 4 ft. XXX strong . . I.75

Mme. Plantier Old-fashioned, double-flowered white rose
2 to $3 \mathrm{ft}$.

ft. Old-fashioned, double-flowered wh

multiflora Japanese white climbing rose

3 to $4 \mathrm{ft}$. . . . . . . $\quad .50 \quad 4.00$

var. catheyensis Cathay rose, a climbing rose with single pink flowers

2 to $3 \mathrm{ft}$. bushy . . . . . $1.00 \quad 9.00$

omlensis Mount Omei Rose A bush rose

18 to 24 in. bushy .... 1. 1.00 9.00

Paradise A climbing rose with single pink flowers

$$
3 \mathrm{ft} . \ldots . . .25 \quad 10.00
$$

Pauline Dawson A Dawson hybrid climber or pillar rose of good foliage and large single deep pink flowers

$$
2 \text { to } 3 \mathrm{ft} \text {. XX strong. . } \quad 1.50
$$

3 to $4 \mathrm{ft}$. spec...... $2 . \mathrm{co}$

Persian Yellow Double deep yellow flowers
2 to $3 \mathrm{ft}$. strong :
I.25 10.00

Purity A large-flowered white climber, similar to Silver Moon, but hardier and flowers more freely

$$
2 \text { to } 3 \text { ft. } 3 \text { yrs.... } 1.50
$$

rugosa repens alba Climbing or creeping white-flowered rugosa hybrid, with glossy foliage and large star-shaped white flowers

$$
2 \mathrm{ft} \text {. spread .... } 2.00
$$

Seashell Dawson hybrid Climber which has glossy foliage and large clusters of large, semi-double pink flowers, blooming in July

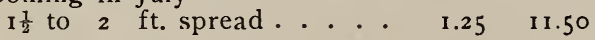

setigera PRAIRIE ROSE, pink

$$
2 \text { to } 3 \mathrm{ft} \text {............. } 45 \quad 3.75
$$

Silver Moon A climber, which has single, cream white flowers
3 to $4 \mathrm{ft}$
1.00
8.50
$1.50 \quad 12.50$ 


\section{Each 10}

Rosa wichuralana Wichurian Rose Single white, climbing or creeping with glossy foliage
2 to $3 \mathrm{ft}$

\section{$\$ .75 \$$}

William C. Egan A Dawson hybrid, climber, with good foliage and large very double pink flowers. Late June. The Egan Rose is one of the very satisfactory climbing Roses. Its foliage is pleasing, and is never attacked by insects, it does not die back in hard winters, and even when very small it is covered with the large, very double fragrant roses
2 to $3 \mathrm{ft}$
3 to 4 ft. . . . . $2.00 \quad 15.00$

All the Roses listed above are thrifty two to three-year old plants which were planted from pots last spring, and will lift with good roots

Splraer arguta GaRLAND SPIREA

2 to $3 \mathrm{ft}$. ......... $450 \quad 4.50$

bumalda ANTHONY WATERER'S SPIREA

12 to 18 in. ......... $50 \quad 4.50$

ovalifolla (callosa alba) White JAPANESE SPIREA

I to $\mathrm{I} \frac{1}{2} \mathrm{ft}$. bushy . . . . $.55 \quad 5.00$

thunbergil Thunberg's SPIREA

2 to $3 \mathrm{ft}$. extra heavy .. $\quad .60 \quad 5.00 \quad \mathbf{4 2 . 0 0}$

3 to 4 ft. extra heavy .. $\quad .70 \quad 6.00 \quad 48.00$

4 to 5 ft. extra heavy . . $.75 \quad 700 \quad 60.00$

5 to $6 \mathrm{ft} . \ldots . . .2$ r. $1.00 \quad 8.00$

van houtteli VAN Houtte SpIREA

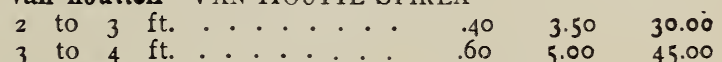

Stephanandra flexuosa Cutleaf Stephanandra

15 to 18 in. ....... $50 \quad 4.50$

Symphoricarpus (conglomerata) chenaulti

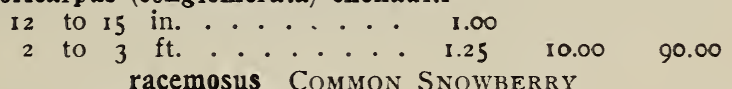

18 to 24 in. . . . . . . . .50 $4.00 \quad 36.00$ vulgaris CORALBERRY

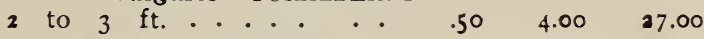

Symplocos panlculata (crataegoldes) Asiatic SweEtLeaf

2 to $3 \mathrm{ft}$........ 3.00

syringa japonica JAPAN TREE LILAC

8 to ro ft. ...... 3.50

vulgaris

2 to $2 \frac{1}{8} \mathrm{ft}$. . . . . . . $1.00 \quad 9.00 \quad 80.00$

var. alba Common White Lilac

2 to $3 \mathrm{ft} . \ldots . . .1 .00 \quad 9.00 \quad 80.00$ var. Charles $\mathrm{X}$ single dark reddish purple

3 to $4 \mathrm{ft}$....... 2.25

var. Ludwig Spath Deep reddish purple

2 to $3 \mathrm{ft}$...... 1.50

var. Marle Legraye Single white

2 to $3 \mathrm{ft}$......... I.50 12.50

var. Michael Buchner Single deep pink

2 to $3 \mathrm{ft}$. heavy.... $1.65 \quad 15.00$ 


\section{Each $10 \quad 100$}

Syringa vulgaris var. Mme. Lemoine Double white, very fine

2 to $2 \mathrm{ft} . \ldots . . . . \$ 1.50 \$ 13.50 \$$

var. Volcan Large, single dark reddish purple

4 to $5 \mathrm{ft}$. ...... 3.75

var. William Robinson Double Pink

2 to $3 \mathrm{ft}$. heavy.... r. $1.65 \mathrm{r} 5.00$

Ulmus americana AMERICAN ELMI

15 to $20 \mathrm{ft}$. 3 to 4 in. cal. . .

$$
8.50 \text { to } 20.00
$$

Viburnum americana AMERICAN CRANBERRYBUSH

2 to $3 \mathrm{ft}$............. $75 \quad 6.50 \quad 60.00$

canbyi CANBY VIBURNUM

3 to 4 ft. .......... $75 \quad 650$

carlesi FRAGRANT VIBURNUM

I to $\mathrm{I} \frac{1}{2} \mathrm{ft} . \ldots . .2 .250 \quad 24.00$

I $\frac{1}{2}$ to $2 \mathrm{ft}$......... $3.00 \quad 28.00$

2 to $2 \frac{1}{2} \mathrm{ft}$. . . . . 5.00

cassinoides. WITHE ROD

2 to $3 \mathrm{ft}$. . . . . . . . 650

3 to $5 \mathrm{ft}$. coll. spec. clps. $\quad 1.50$

dentatum ARROw

2 to $3 \mathrm{ft}$. . . . . . . $75 \quad 6.00 \quad 50.00$

3 to $4 \mathrm{ft}$............. $90 \quad 7.50 \quad 65.00$

4 to $5 \mathrm{ft}$. . . . . . 1.25 10.00

dilatatum LINDEN VIBURNUM

5 to $6 \mathrm{ft}$. . . . . 3.50

6 to $7 \mathrm{ft} . \ldots . . . .55 .00$

opulus European Cranberry Bush

2 to $3 \mathrm{ft}$........... $75 \quad 6.50$

pubescens Downy Viburnum

2 to $2 \frac{1}{8} \mathrm{ft}$. . . . . . $1.00 \quad 9.00$

Zenobia pulverulenta (Andromeda speciosa) Dusty Zenobia

$\mathrm{I} \frac{1}{2}$ to $2 \mathrm{ft}$...... 3.00 


\section{HARDY HERBACEOUS PERENNIALS}

Except where noted 30 cents each, $\$ 2.40$ per ten $\$ 18.00$ per hundred

25 perennials of one kind are priced at the hundred rate when a hundred rate is listed

Each $10 \quad 100$

Achillea ptarmica "The PEARL" SNEEZEwort

Aconitum acutum EARLy ACONITE . $\quad .40 \quad 3.50 \quad 25.00$

Ajuga genevensis CREEPING BUGLE

Alyssum saxatile compactum GOLD-DUST

Anthericum liliago ST. BERNARD'S LILY

Aquilegia californica HYBRIDS

canadensis American Columbine

chrysantha Golden Columbine

coerulea Colorado Columbine

delicatissimum Long-spurred hybrids

nivea grandiflora Munstead White Columbine

Rose Queen Pink, long-spurred hybrids

Arenaria caespitosa Moss SANDWORT

Asclepios tuberosa BUtTERFLY WeED $.35 \quad 3.00$

Aster alpina Rock Aster

Novae Angliae rubra Rosy New England Aster

St. Egwyn Bright pink

$$
\text { Tall, rose pink }
$$

Astible japonica JAPANESE AStible $\quad .35 \quad 3.00$

Baptisla australis WILD-INDIGO

Boltonia asteroides White BoLTONIA

latisquama ViOLET BoltoniA

Buddleia magniflca OXEYE BUTTERFLY

2 yrs..... $.50 \quad 4.00$

Callirhoe involucrata Low PopPy-MaLlow

.50

Campanula carpatica CARPATHian Bellflower

persieaefolia PEACHLEAF BELlfLOWER alba Petticoat Bellflower

Centaurea montana Mountain Bluet

Cerastlum blebersteimi TAURUS CERASTIUM

Chrysanthemum maximum SHASTA DAISY

Coreopsis grandiflora BIG COREOPSIS

Daphne cneorum Rose DAPHNE

2 yr. clumps .... 1.00

Delphineum chinense SLENDER LARKSPUR blue and white var. Blue Butterfly New

hybridum MOUNTAIN LARKSPUR

Bella Donna Light blue bellamosum

mixed

dark blue form of Belladonna

For prices see pages $11-12$ 
Dianthus barbatus SWEET WILLIAM red, white, pink beauty plumarius Grass PINK

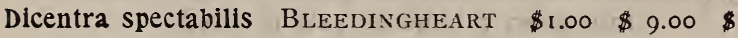

Digitalis ambigua Foxglove Yellow

alba FoxgLove White

purpurea Comion Foxglove

Echinops rito SteEl GLobethistLe

Eryngium amethystinum AMETHYST ERINGO

Festuca glauca Fescoe Grass Blue

Gaillardia aristata ( $\mathrm{gr} . \mathrm{fl}$.) Common Perennial Galllardia Gillenia stipulata INDIAN-PHYSIC

Gypsophila paniculata BABY'S BREATH $\quad .50$

repens CREEPING BABY'S BREATH

Helianthus mollis var. cordatus

Hemerocallis Apricot DAYLILY Yellow dumortieri DAYLILY Early

flava DAYLILY Lemon

fulva DAYLILY Tawny

thunbergil JAPANESE DAYLILY

Hibiscus hybriaus Rosemallow giant pink and white

Hosta (Funkia) lancifolia $4.50 \quad 4.50$

Hypericum buckleyi MOUntain St. Johnswort

Iberis sempervirens EvERGREEN CANDYTUFT

$.75 \quad 650$

var, LitTi.e Gem

Iris Celeste Blue

Dwarf Evergreen Candytuft

Florentina FLORENTINE IRIS White

germanica GERMAN IRIS

Blue Jay (Farr's) light and dark blue $\quad .75 \quad 7.00$

Charlotte Patty golden yellow

Chester J. Hunt (Farr's) dark marine blue

$.75 \quad 7.00$

Dr. Bernice coppery bronze, crimson .45

Erich (Farr's) bright, light violet, flushed rose

Fairy Queen white, falls veined in blue

$.75 \quad 7.00$

Frich (Farr's) Garrick standards light blue falls a dark blue Hiawatha (Farr's) pale lavender, flushed rose I.00 9.00

Juniata (Farr's) clear blue, deeper than dalmatica fragrant flowers

Mary Garden (Farr's) pale yellow, and lavender .45

Mme. Chereau white, edges of petals blue 
HARDY HERBACEOUS PLANTS

Each 10

Iris Kaempfert Gold Bound white Japanese Iris

$$
\$ .50 \$ 4.00 \$
$$

monsignor satiny velvet; falls overlaid rich purple crimson, fine large flowers

Quaker Lady (Farr's)

s. smoky lavender with yellow shadings

f. ageratum blue and old gold

Rhein nixe ( $G \& K$ I910)

$$
.50 \quad 4.50
$$

s. pure white

f. deep violet blue with white edge

kaempferi laevigata JAPANESE IRIS $\begin{array}{rr}.50 & 4.20\end{array}$

pallida Dalmatica...... . . . $35 \quad 3.00$

Speciosa ......

pumila dwarf, deep purple

pseudacorus YELLOW FLAG

siberica SIBERIAN IRIS

alba SibERIAN IRIS White

$\begin{array}{llll}\text { orientalis ORIENTAL IRIS } & .25 & 2.20 & 15.00 \\ \text { Snow Queen ORIENTAL IRIS } & .25 & 2.20 & 15.00 \\ & .25 & 2.20 & 15.00\end{array}$

Liatris spicata SPIKe Gayfeather

$\begin{array}{lll}25 & 2.20 & 15.00\end{array}$

Lillum auratum Gold Band Japan Lily $\quad .65 \quad 5.00$

candidum Madonna Lily, large size

$\begin{array}{ccc} & .50 & 4.00 \\ \text { mammoth } & .75 & 6.50 \\ \text { enry Lily } & .75 & 7.00 \\ \text { oyal Lily } & .75 & 7.00\end{array}$

$\begin{array}{llll}\text { Henryi Henry Lily } & .75 & 7.00 \\ \text { regale } & \text { Royal Lily } & .75 & 7.00\end{array}$

speciosum album white speciosum Lily

$$
\begin{array}{ccc} 
& \multicolumn{3}{c}{\begin{array}{c}
.75 \\
\text { var. magnificum }
\end{array}} & 6.50 \\
\text { Great speciosum Lily } & .60 & 5.00 \\
\text { tigrinum splendens Giant Tiger Lily } & \\
.35 & 3.00
\end{array}
$$

Linum perenne Perennial Flax

Lipachys pinnata Yellow CONE Flower

Lysimachia nummularia MONEYwORT

vulgaris GOLDEN LOOSESTRIFE

Lythrum salicaria PURPLE LoOsestrife

Nepeta Mussini

Denothera fruticosa youngi Youngs SUNDRoPS

missouriensis Ozark Sundrops

Paeonias mixed large clumps ... . $\quad 60 \quad 5.50$

Phlox amoena DwARF PhLOx

paniculata Albion white with pink eye

Antoine Mercie pale lilac, white star in center

Aurora Borealis Salmon scarlet, deep crimson eye

B. Comte Rich, dark crimson red, late blooming 
Phlox paniculata

$$
\text { Each } 10
$$

Bridesmaid White with large rosy center Cyclone white, dark carmine eye

Czarina fine white, tall and late

Eclaireur deep carmine, rosy salmon center Ettas Choice pure white

H. 0. Wijers white, with large red eye. Low Independence white, medium, early

Jean d'Arc tall, late, white

Mrs. Cook tall, soft magenta pink, very late

Richard Wallace white, deep crimson eye

Saison Lierval white, with light pink eye

Widor bright reddish violet, large white center

William Muhle Bright pink, tall, late

Phlox subulata Moss PINK . . . . $\$ .25 \quad \$ 2.20 \quad \$ \quad 15.00$ alba White Moss

$\begin{array}{lllll}\text { lilacina LILAC MOSS } & .25 & 2.20 & 15.00\end{array}$ var. G. F. Wilson LAvender Moss var. Vivid PINK Moss

Physostegia virginica FALSE DRAGONHEAD

$\begin{array}{lll}.35 & 3.00 \quad 24.00\end{array}$

Platycodon grandiflora BALLOONFLOWER

Rudbeckia purpurea HEDGEHOG-CONEFlower

Salvia azurea grandiflora GreAt AzURE SAGE

Sedum acre Goldmoss

lydium roseum LYDIAN STONECROPE

sarmentosum Stringy

sexangulare Hexagon

spectabilis Showy

stoloniferum Running

Sempervivum arenarium SAND HoUSElEEK

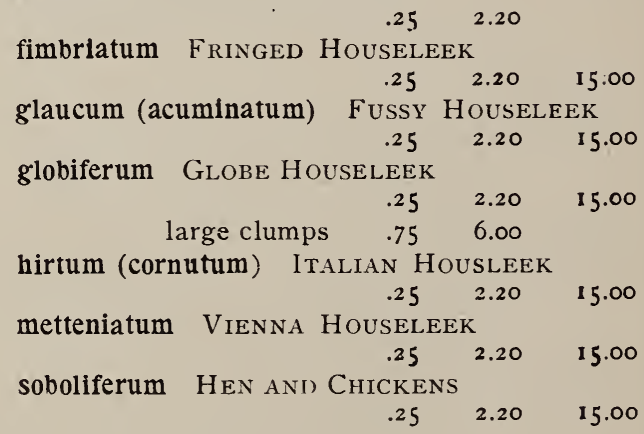


HARDY HERBACEOUS PLANTS

Sempervivum tectorum Roof HousELEEK

large clumps

$$
\$ .25 \$ 2.20 \$ 15.00
$$

var. violaceum ViOLET HoUSELEEK

Silene maritima SEA CATChFLy

Statice latifolia Bigleaf SEA LAvender

Stellaria holostea EASTERBELLS

Thymus serpyllum MOTHER OF THYME coccineum CRIMSON THYME lanuginosus Woolly Thyaie

Tradescantia virginiana VIRGINIA SPIDERWORT

Tunica saxifraga SAXIFRAGE TUNICFLOWER Vernonia noveboracensis COMMON IRONWEED

Veronica alpestris See V. serpilifolia

gentianoides Gentian SPEEdivell

rupestris Rock SPEEDWELL

var. pink

spicata SPIKE SPEEDWELL

var. Maxima Tall Speedwell 


\section{HOW TO REACH OUR NURSERIES}

By train: Take train from South Station, Boston, or from Worcester and other points west, to Framingham. From Framingham, take train or electric car to Holliston. Upon being notified we will be glad to meet at Holliston any persons desiring to visit the Nurseries. Telephone Natick 345 .

By motor: From Boston the best route is via Newton, Wellesley, South Natick; from South Natick take Elliot Street, to Main Street, Sherborn, thence Main Street, Goulding Street, Mill Street, Fiske Street to the Nurseries.

From Worcester take main route to Framingham, from Framingham follow the street car track to Holliston Centre, turn sharp to left up Central Street, thence Fiske Street to the Nurseries. 